\title{
EFFECT OF CANOPY GAPS AND TOPOGRAPHIC REGIMES IN SEEDLINGS PERFORMANCE IN SINHARAJA RAIN FOREST, SOUTHWEST SRI LANKA
}

\author{
${ }^{1}$ EPSK Ediriweera, 'BMP Singhakumara and ${ }^{2}$ PMS Ashton \\ ${ }^{1}$ Department of Forestry and Eıvironmental Science, \\ University of Sri Jayewardenepura, Nugegoda \\ ${ }^{2}$ Yale University, New Haven, U.S.A.
}

\begin{abstract}
Growth and survival of tree canopy dominant seedliags in the Sinharaja lowland rain forest in southwest Sri Lanka were monitored. Twelve crilopy gaps and closed canopy sites were selected, as four of each on different topographe positions- valley, midslope and ridgetop. Measurements of height, number of leaves and mortality were recorded over a two-year period. Hemispherical canopy photographs were taken to calculate Indirect Site Factor (ISF), Direct Site Factor (DSF), and canopy openness. Greatest caropy openness, highest DSF values were recorded for ridgetop sites and smallest values were recorded for valley sites. Over the two-year period sixty-six (11.45\%) seedlings died in the ridge top, which indicated the highest mortality rate. Survival of seedlings in the canopy gap anc orest understorey declined on progressing from valley to ridgetop sites. Seedlings of Mesua fe reea had a higher survival than other species in the canopy opening and understorey conditions. Height growth and leaf number were greatest in the gap sites. A significant relationship was found between DSF and maximum height growth (33.05,P>0.00) for Syzygium rubicundum. Shorea irapezifolia, Shorea disticha and Syzygium rubicundum showed greatest height increment in the valley, midslope and ridgetop sites respectively. No relationship was found between DSF and leaf numbers in all seedlings except Syzygium rubicundum, where has increased with increasing DSF.
\end{abstract}

